九州大学学術情報リポジトリ

Kyushu University Institutional Repository

Formation of Indigestible Materials and

Increase in Dry Matter Indigestibility in the Growth of Two Tropical Forages

Shimojo, Masataka

Laboratory of Animal Feed Science, Faculty of Agriculture, Kyushu University

Imura, Yoshimi

Laboratory of Animal Feed Science, Faculty of Agriculture, Kyushu University

Tobisa, Manabu

Laboratory of Animal Feed Science, Faculty of Agriculture, Kyushu University

Koga, Naoki

Laboratory of Animal Feed Science, Faculty of Agriculture, Kyushu University

他

https://doi.org/10.5109/24196

出版情報 : 九州大学大学院農学研究院紀要. 42 (1/2)，pp.95-99，1997-12. Kyushu University バージョン：

権利関係 : 


\title{
Formation of Indigestible Materials and Increase in Dry Matter Indigestibility in the Growth of Two Tropical Forages
}

\author{
Masataka Shimojo, Yoshimi Imura, Manabu Tobisa, Naoki Koga, \\ Takashi Bungo, Yutaka Nakano*, Takayoshi Nishihira**, \\ Ichiro Goto and Yasuhisa Masuda
}

\author{
Laboratory of Animal Feed Science, Faculty of Agriculture, \\ Kyushu University, Fukuoka 812-81, Japan \\ (Received July 31, 1997 and accepted August 25, 1997)
}

This study was conducted to analyze the formation of indigestible materials [equation (A)] and the increase in dry matter indigestibility [equation (B)] in the growth of Rhodes grass (Rg) and Greenleaf desmodium (Gd).

$\frac{1}{W} \cdot \frac{d I}{d t}=\frac{C}{W} \cdot\left(\frac{1}{C} \cdot \frac{d L}{d t}\right) \cdot \frac{d I}{d L}$,

where $(1 / W) \cdot(d I / d t)=$ formation rate of $I$ (indigestible materials) per unit $W$ (forage dry weight) $[\mathrm{FRI}, C / W=$ the ratio of $C$ (cell wall constituents) to $W$ [CWC ratio], $(1 / C) \cdot(d L / d t)=$ formation rate of $L$ (lignin) per unit $C$ [Specific FRL], $d I / d L=$ formation of $I$ per unit increase in $L$ [FIL].

$\frac{I_{2}}{W_{2}}-\frac{I_{1}}{W_{1}}=\left(1-\frac{W_{1}}{W_{2}}\right) \cdot\left(\frac{\overline{\text { FRI }}}{\overline{\mathrm{RGR}_{\mathrm{w}}}}-\frac{I_{1}}{W_{1}}\right)$,

where $\left(I_{2} / W_{2}-I_{1} / W_{1}\right)=$ increases in dry matter indigestibility [IDMI], $W_{1} \neq W_{2},\left(1-W_{1} / W_{2}\right)=$ forage growth index $\left[\mathrm{FG}\right.$ index], $\overline{\mathrm{RGR}_{\mathrm{w}}}=$ mean relative growth rate of forage,

$\overline{\mathrm{FRL}} / \overline{\mathrm{RGR}}_{\mathrm{w}}-I_{1} / W_{1}$ ) = index for dry matter partition into indigestible materials [DMP index].

Each attribute was given a bar on it to show mean value over the interval $t_{1}$ to $t_{2}$.

The results obtained were as follows.

1. FRI was higher in Rg than in Gd and this was due to both higher $\overline{\mathrm{CWC} \text { ratio }}$ and higher $\overline{\mathrm{FIL}}$ in $\mathrm{Rg}$.

2. IDMI was larger in Rg compared to Gd, which was due to higher DMP index with some contribution by FG index.

It was suggested that this method was available for a macro analysis of the change in dry matter indigestibility occurring in the growth of forages.

\section{INTRODUCTION}

Those people who are engaged in the production of ruminants from forages should pay attention to the forage quality which affects the intake and productivity in animals (Van Soest, 1982; Minson, 1990a). Among the forage qualities dry matter digestibility is one of the major concerns to be taken up in the forage breeding programs.

As a forage plant grows its dry matter digestibility generally falls due to a increase in the proportion of indigestible materials. A study by Masuda (1985) is probably a pioneering one in which the process of changes in forage indigestibility during growth was

* Kyushu University Farm, Fukuoka 811-23.

** KANEKO SEEDS CO., LTD., Gunma 372. 
analyzed using simple equations. This sort of analytical approach is considered important from a practical point of view, though in a micro level investigation there are complicated relationships between cell wall components and digestibility in forages (Jung and Allen, 1995). Shimojo et al. (1995) also presented a simple method for analyzing the formation of indigestible materials and increases in dry matter indigestibility, and applied it to some tropical grasses.

The present study was designed to apply this analytical method to a grass and a forage legume of tropical species which might be expected to show different tendencies in the formation of indigestible materials and in the increase in dry matter indigestibility during growth.

\section{MATERIALS AND METHODS}

\section{Forage samples and their characteristics}

Forages used in the present study were Rhodes grass (Chloris gayana Kunth) and Greenleaf desmodium (Desmodium intortum (Mill.) Urb.). They were regrowth forages cut at 35 and 63 days after the first cut and discard followed directly by the dressing of a compound fertilizer $\left(\mathrm{N}: \mathrm{P}_{2} \mathrm{O}_{5}: \mathrm{K}_{2} \mathrm{O}=14: 14: 14 \%\right)$ at a rate of $1.0 \mathrm{~kg} / \mathrm{a}$ for each element.

The characteristics of Rhodes grass (Rg) and Greenleaf desmodium (Gd) are shown in Table 1. The contents of cell wall constituents and lignin in forages were determined using the method by Goering and Van Soest (1970). The effects of silica on forage digestibility (Van Soest, 1982; Minson, 1990b) were not taken into account.

Table 1. Characteristics of Rhodes grass (Rg) and Greenleaf desmodium (Gd).

\begin{tabular}{|c|c|c|c|c|}
\hline \multirow{2}{*}{$\begin{array}{l}\text { Forages } \\
\text { Regrowth (days) }\end{array}$} & \multicolumn{2}{|c|}{$\mathrm{Rg}$} & \multicolumn{2}{|c|}{ Gd } \\
\hline & 35 & 63 & 35 & 63 \\
\hline Dry matter digestibility ${ }^{1)}(\%)$ & 63.93 & 49.93 & 55.71 & 52.95 \\
\hline Dry matter indigestibility $^{1)}(\%)$ & 36.07 & 50.07 & 44.29 & 47.05 \\
\hline Cell wall constituents: CWC (\%) & 73.80 & 77.89 & 51.49 & 57.02 \\
\hline $\operatorname{Lignin}^{21}(\%)$ & 3.07 & 5.88 & 7.06 & 7.72 \\
\hline Dry weight (DW) of forage: $W\left(\mathrm{~g} / \mathrm{m}^{2}\right)$ & 225.56 & 515.00 & 190.00 & 315.28 \\
\hline DW of indigestible materials: $I\left(\mathrm{~g} / \mathrm{m}^{2}\right)$ & 81.36 & 257.87 & 84.16 & 148.35 \\
\hline Amount of CWC: $C\left(\mathrm{~g} / \mathrm{m}^{2}\right)$ & 166.47 & 401.14 & 97.84 & 179.76 \\
\hline Amount of lignin: $L\left(\mathrm{~g} / \mathrm{m}^{2}\right)$ & 6.93 & 30.26 & 13.41 & 24.33 \\
\hline
\end{tabular}

1) In vitro determination using rumen fluid of goats and pepsin.

2) Acid detergent lignin.

\section{Analytical methods}

(1) Formation of indigestible materials in the growth of forage

According to our previous paper (Shimojo et al., 1995) the following equation was used to analyze the formation of indigestible materials.

$$
\frac{1}{W} \cdot \frac{d I}{d t}=\frac{C}{W} \cdot\left(\frac{1}{C} \cdot \frac{d L}{d t}\right) \cdot \frac{d I}{d L}
$$


where $\mathrm{W}=$ dry weight of forage, $I=$ dry weight of indigestible materials, $L=$ amount of lignin, $C=$ amount of cell wall constituents $[C W C],(1 / W) \cdot(d I / d t)=$ formation rate of $I$ per unit $W$ [FRI], $C / W=$ the ratio of $C$ to $W$ [CWC ratio], $(1 / C) \cdot(d L / d t)=$ formation rate of $L$ per unit $C$ [Specific FRL], $d I / d L=$ formation of $I$ per unit increase in $L$ [FIL].

In equation (1) lignin was related to both cell wall lignification and formation of indigestible materials with forage growth, which is based on the strong negative correlations between lignin content and cell wall digestion in forages sampled at a range of maturities (Jung and Allen, 1995). Thus, FRI was evaluated using CWC ratio, specific FRL and FL.

The mean value over the interval $t_{1}$ to $t_{2}$ for each of FRI, CWC ratio, Specific FRL and FIL was approximately as follows:

$$
\begin{aligned}
& \overline{\text { FRI }}=\frac{\log W_{2}-\log _{1} W_{1}}{W_{2}-W_{1}} \cdot \frac{I_{2}-I_{1}}{t_{3}-t_{1}}, \\
& \overline{\text { CWC ratio }}=\frac{C_{2}-C_{1}}{\log C_{2}-\log C_{1}} \cdot \frac{\log W_{2}-\log W_{1}}{W_{2}-W_{1}}, \\
& \overline{\text { Specific FRL }}=\frac{\log C_{2}-\log C_{1}}{C_{2}-C_{1}} \cdot \frac{L_{2}-L_{1}}{t_{2}-t_{1}}, \\
& \overline{\text { FIL }}=\frac{I_{2}-I_{1}}{L_{2}-L_{1}},
\end{aligned}
$$

where e is the base of natural logarithm.

(2) Increase in dry matter indigestibility with forage growth

The increase in dry matter indigestibility [IDMI] over the interval $t_{t}$ to $t_{2}$ that incorporated FRI into it was described as follows:

$$
\begin{aligned}
\text { IDMI } & =\frac{I_{2}}{W_{2}}-\frac{I_{1}}{W_{1}} \\
& =\left(1-\frac{W_{1}}{W_{2}}\right) \cdot\left(\frac{\overline{\mathrm{FRI}_{2}}}{\mathrm{RGR}_{\mathrm{W}}}-\frac{I_{1}}{W_{1}}\right),
\end{aligned}
$$

where $W_{1} \neq W_{2},\left(1-W_{1} / W_{2}\right)=$ forage growth index $\left[\mathrm{FG}\right.$ index], $\overline{\mathrm{RGR}}_{\mathrm{w}}=$ mean relative growth rate of forage over the interval $t_{1}$ to $t_{2}$, $\left(\overline{\mathrm{FRI}} / \mathrm{RGR}_{w}-I_{1} / W_{1}\right)=$ index for dry matter partition into indigestible rnaterials [DMP index].

It was suggested in equation (6) that IDMI was divided into growth part and indigestible part of a forage, and thus, IDMI was evaluated using FG index and DMP index.

\section{RESULTS AND DISCUSSION}

\section{Analysis of the formation of indigestible materials in the growth of two forages}

The results for the analysis of the formation of indigestible materials in $\mathrm{Rg}$ and $\mathrm{Gd}$ in the growth from 35 to 63 days are shown in Table $2 \mathrm{a}$.

FRI over 28 day-growth for Rg was almost twice as high as that for Gd. $\overline{\text { CWC ratio }}$ was higher in Rg than in $\mathrm{Gd}$, which was associated with higher content of $\mathrm{CWC}$ in $\mathrm{Rg}$ compared to Gd. Specific FRL showed only a small difference between two forages, implying that $\mathrm{Rg}$ and $\mathrm{Gd}$ were similar in the extent of cell wall lignification from the analytical point of view. FIL for RG was higher than that for Gd, and this suggested that 
Table 2. Analysis of formation of indigestible materials and of increases in dry matter indigestibility in the growth of Rhodes grass ( $\mathrm{Rg}$ ) and Greenleaf desmodium (Gd).

a) Analysis of formation of indigestible materials

\begin{tabular}{llll}
\hline Forages & $\mathrm{Rg}$ & $\mathrm{Gd}$ & $\mathrm{Rg} / \mathrm{Gd}$ \\
Interval (dãys) & 28 & 28 & \\
\hline$\overline{\text { FRI }(\mathrm{g} / \mathrm{g} / \text { day) }}$ & 0.0180 & 0.0093 & 1.9403 \\
\hline CWC ratio $(\mathrm{g} / \mathrm{g})$ & 0.7611 & 0.5444 & 1.3980 \\
Specific FRL $(\mathrm{g} / \mathrm{g} /$ day) & 0.0031 & 0.0029 & 1.0783 \\
FIL $(\mathrm{g} / \mathrm{g})$ & 7.5658 & 5.8782 & 1.2871 \\
\hline
\end{tabular}

FRI: formation rate of indigestible materials per unit of forage dry weight, CWC ratio: the ratio of cell wall constituents to forage dry weight, Specific FRL: formation rate of lignin per unit of cell wall constituents, FII: formation of indigestible materials per unit increase in lignin.

b) Analysis of increase in dry matter indigestibility (IDMI)

\begin{tabular}{llcc}
\hline Forages & $\mathrm{Rg}$ & $\mathrm{Gd}$ & $\mathrm{Rg} / \mathrm{Gd}$ \\
\hline IDMI & 0.1400 & 0.0276 & 5.0755 \\
FG index & 0.5620 & 0.3974 & 1.4144 \\
DMP index & 0.2491 & 0.0694 & 3.5885 \\
\hline
\end{tabular}

IDMI: increases in dry matter indigestibility,

FG index: forage growth index,

DMP index: index for dry matter partition into indigestible materials.

the extent to which indigestible materials was formed per unit increase in lignin was higher for Rg than for $\mathrm{Gd}$.

Therefore, higher $\overline{\mathrm{FRI}}$ in Rg than in Gd is mainly due to both higher $\overline{\mathrm{CWC} \text { ratio }}$ and higher FIL in Rg. These results are associated with implications by Jung and Allen (1995) that reducing cell wall concentration is a target for improvement of grasses, whereas improving cell wall digestibility is a more important target for forage legumes.

\section{Analysis of increase in dry matter indigestibility with growth of two forages}

The results for the analysis of the increase in IDMI are shown in Table $2 \mathrm{~b}$. There was a larger IDMI for Rg compared to Gd. FG index was higher in Rg than in Gd. DMP index of Rg was much higher than that in Gd. Larger IDMI in Rg compared to Gd was due to higher DMP index with some contribution by FG index. Thus, the difference in IDMI between Rg and Gd may be probably related to the difference in FRI between two forages.

The underestimation of lignin content caused by the use of acid detergent lignin is somewhat larger in grasses than in forage legumes (Shimojo and Goto, 1987; Jung and Allen, 1995). The content of silica is generally higher in grasses compared to legumes (Wilson, 1982). There will be, therefore, some modifications in the results of analyses if there occurs a selection for the method of lignin determination and/or an incorporation of the effects of silica (Van Soest, 1982; Minson, 1990b).

In the present study using FRI and IDMI an analytical explanation was given to the 
formation of indigestible materials and the dry matter indigestibility increases during the growth which showed different tendencies between a grass and a forage legume of tropical species. It is suggested that this method is available for a macro analysis of the change in dry matter indigestibility occurring in the growth of forages.

\section{ACKNOWLEDGEMENTS}

The authors thank Dr. Mitsuhiro Furuse for useful comments on this paper and Mr. Yasukatsu Yano for skilled technical assistance in the present work.

\section{REFERENCES}

Goering, H. K. and P. J. Van Soest 1970 Forage fiber analyses. Agriculture Handbook (U. S. D. A.), No. 379: $1-20$

Jung, H. G. and M. S. Allen 1995 Characteristics of plant cell walls affecting intake and digestibility of forages by ruminants. J.Anim.Sci, 73: 2774-2790

Masuda, Y. 1985 Analysis of dry matter digestibility of green panic as affected by the change in temperature. Proc.XV Int.Grassl. Congr, 1009-1011

Minson, D. J. 1990a Ruminant production and forage nutrients. In "Forage in Ruminant Nutrition", Academic Press, Inc., San Diego, pp. 1-8

Minson, D. J. 1990b Digestible energy of forage. In "Forage in Ruminant Nutrition", Academic Press, Inc, San Diego, pp. 85-149

Shimojo, M. and I. Goto 1987 A study on the relation between organic matter disappearance and acetyl bromide lignin of tropical forages. Jpn.J. Zootech.Sci, 58: 750-753

Shimojo, M., Y. Masuda, T. Bungo, T. Kawamura and I. Goto 1995 Analytical expression for formation of indigestible materials and increase in dry matter indigestibility with growth of some tropical grasses. J. Fac. Agr, Kyushu Univ, , 40: 179-188

Van Soest, P. J. 1982 Nutritional quality. In "Nutritional Ecology of the Ruminant", Cornell University Press, New York, pp. 23-74

Wilson, J. R. 1982 Environmental and nutritional factors affecting herbage quality. In "Nutritional Limits to Animal Production from Pastures", ed.by J. B. Hacker, CAB International, Farnham Royal, U. K., pp. $111-131$ 